\title{
KARAKTERISTIK DAN PENGGUNAAN ANTIBIOTIK PADA PASIEN DEMAM TIFOID DI BEBERAPA RUMAH SAKIT DI SAMARINDA PERIODE 2015
}

\author{
Sri Andriani Allo Bulawan*, Jaka Fadraersada, Laode Rijai \\ Fakultas Farmasi UniversitasMulawarman, Samarinda, Kalimantan Timur \\ *Email: sriandriani44@gmail.com
}

\begin{abstract}
ABSTRAK
Demam tifoid merupakan penyakit endemik yang termasuk dalam masalah kesehatan di negara berkembang termasuk di Indonesia. Penyakit ini merupakan penyakit menular yang disebabkan oleh Salmonella typhi. Tujuan dari penelitian ini untuk mengetahui karakteristik dan penggunaan antibiotik pada pasien demam tifoid dibeberapa Rumah Sakit di Samarinda. Metode yang digunakan adalah metode analisis secara deskriptif. Pemilihan sampel penelitian dilakukan dengan rancangan probability sampling menggunakan teknik cluster sampling. Hasil penelitian menunjukkan karakteristik pasien demam tifoid tertinggi berdasarkan jenis kelamin adalah laki-laki $(52,22 \%)$, berdasarkan usia adalah kelompok umur 18-40 tahun (80 \%), berdasarkan pendidikan adalah SD $(42,68 \%)$ dan berdasarkan pekerjaan adalah swasta $(46,43 \%)$. Penggunaan antibiotik terbanyak pada sefalosporin generasi ketiga yaitu seftriakson $(52,22 \%)$.
\end{abstract}

Kata kunci : Karakteristik pasien, antibiotik, demam tifoid

\begin{abstract}
Typhoid fever is an endemic disease that is included in health issues in developing countries, including Indonesia. This disease is an infectious disease caused by Salmonella typhi. The purpose of this study to know the characteristics and use of antibiotics in patients with typhoid fever at several Hospitals in Samarinda which include age, gender, education and employment. The method used is descriptive analysis method. Selection of research sample conducted with probability sampling design using cluster sampling technique. The results showed the highest typhoid fever patient characteristics based on gender is male (52.22\%), based on age is the age group 18-40 years (80\%), based on education is SD (42.68\%) and based on the work is private (46.43\%). Most antibiotic use in third generation cephalosporin is ceftriaxone (52.22\%).
\end{abstract}

Keywords: Antibiotics, characteristics of patients, , typhoid fever

\section{PENDAHULUAN}

Penyakit menular masih merupakan salah satu masalah kesehatan utama di negara berkembang. Salah satu penyakit menular tersebut adalah demam tifoid. Penyakit ini merupakan penyakit menular yang disebabkan oleh Salmonella typhi. Demam tifoid banyak ditemukan dalam kehidupan masyarakat baik diperkotaan maupun di pedesaan (Ayu dkk., 2012).

Demam tifoid merupakan penyakit endemik yang termasuk dalam masalah kesehatan di negara berkembang termasuk di Indonesia. Diperkirakan menyerang 22 juta 
orang pertahun dengan angka kematian mencapai 200.000 jiwa per tahun (Puspitasari dan Eman, 2011). Berdasarkan profil kesehatan Indonesia 2007, demam tifoid menduduki peringkat ke 3 dari 10 penyakit terbanyak pada pasien rawat inap di Rumah Sakit (Depkes RI, 2007). Berdasarkan laporan hasil Riset Kesehatan Dasar (Riskesdas) provinsi tahun 2007, prevalensi demam tifoid di Kalimantan Timur sebesar 1,31\% dan menempati peringkat ketiga tertinggi dibandingkan dengan provinsi lain (Balitbangkes, 2008).

Demam tifoid adalah penyakit infeksi sistemik yang disebabkan oleh bakteri Salmonella enterica, khususnya serotype Salmonella typhi. Bakteri ini termasuk gram negatif yang memiliki flagel, tidak berspora, motil, berbentuk batang, berkapsul dan bersifat fakultatif anaerob dengan karakteristik antigen O, H dan Vi (Fauci, 2008).

Sumber penularan utama demam tifoid adalah penderita itu sendiri dan carrier yang mana mereka dapat mengeluarkan berjuta-juta kuman Salmonella typhi dalam tinja, dan tinja inilah yang menjadi sumber penularan. Debu yang berasal dari tanah yang mengering, membawa bahan-bahan yang mengandung kuman penyakit yang dapat mencemari makanan yang dijual di pinggir jalan. Debu tersebut dapat mengandung tinja atau urin dari penderita atau carrier demam tifoid. Bila makanan dan minuman tersebut dikonsumsi oleh orang sehat maka rawan tertular penyakit infeksi demam tifoid. Infeksi demam tifoid juga dapat tertular melalui makanan dan minuman yang tercemar kuman yang dibawa oleh lalat (Puspitasari dan Eman, 2011).

Keputusan dokter dalam memilih obat dipengaruhi oleh beberapa faktor antara lain pengetahuan tentang farmakologi/farmakoterapi, pendidikan yang berkelanjutan, pengalaman, psikologi dan informasi obat yang diterima. Selain faktor tersebut, faktor lain seperti diagnosis, obat itu sendiri dan karakteristik pasien juga mempengaruhi dokter dalam pemilihan atau alternatif pengobatan (Musnelina., 2004). Oleh sebab itu, penting untuk mengetahui karakteristik dari pasien demam tifoid, agar pengobatan yang diberikan tepat dan sesuai.

Penggunaan antibiotik yang tidak tepat dapat menimbulkan kegagalan terapi dan berbagai masalah seperti ketidaksembuhan penyakit, resistensi dan meningkatkan efek samping obat. Sebab terjadinya kegagalan terapi seperti pemberian dosis kurang, masa terapi kurang dan pemilihan antibiotik yang kurang tepat. Bila pemberian antibiotik berlebihan dan tidak tepat dapat menyebabkan resistensi dan meningkatkan biaya pengobatan serta efek samping dari antibiotik. Penggunaan antibiotik yang terlalu banyak dapat menimbulkan masalah atau yang dikenal dengan polifarmasi. Akibat dari polifarmasi yaitu timbulnya interaksi obat dan efek samping yang semakin besar. Apabila interaksi antara obat dengan mikroba kurang baik atau tidak terjadi sama sekali, maka dikatakan bahwa antibiotik tersebut telah resisten terhadap mikroba tertentu akibatnya muncul Multi Drug Resistance Salmonella typhi (MDRST).

Prevalensi resistensi antibiotik meningkat setiap tahun. Pada tahun 2013 di Amerika Serikat, setiap tahun setidaknya 2 juta orang terkena infeksi bakteri yang resisten terhadap satu atau beberapa jenis antibiotik. Hal ini semakin diperparah dengan data yang menunjukkan bahwa sekitar 23.000 orang meninggal setiap tahun karena mendapat infeksi bakteri yang telah resisten terhadap antibiotik (Arias dan Barbara, 2015). Pada tahun 19942010, terdapat 440.000 kasus akibat resistensi antibiotik yang setidaknya telah menyebabkan 150.000 kematian di 64 negara temasuk Indonesia (Kamriyani dkk., 2013).

Tujuan dari penelitian ini adalah mengetahui karakteristik pasien demam tifoid dibeberapa Rumah Sakit Samarinda dan mengetahui penggunaan antibiotik pada pasien demam tifoid di beberapa Rumah Sakit di Samarinda. 


\section{METODE PENELITIAN}

Populasi dalam penelitian ini adalah pasien demam tifoid di RSUD Abdoel Wahab Sjahranie Samarinda, RSUD I.A Moeis Samarinda dan RS Islam Samarinda. Kriteria inklusi penelitian ini adalah pasien demam tifoid yang dirawat inap di Rumah Sakit Samarinda sedangkan kriteria eksklusi adalah pasien demam tifoid dengan penyakit penyerta dan pasien dengan kondisi hamil.

Penelitian ini berupa penelitian survei non eksperimental dan menggunakan metode deskriptif dengan pengambilan data secara retrospektif yaitu penelitian yang melihat kebelakang (backward looking) dengan melakukan pencatatan dari rekam medik pasien yang didiagnosis demam tifoid.

Pencarian data rekam medik masing-masing pasien berdasar nomor rekam medik yang telah tercatat sebelumnya di buku registrasi. Data yang masuk ke dalam kriteria inklusi kemudian dianalisis secara deskriptif dan diolah menjadi bentuk persentase serta disajikan dalam bentuk tabel atau diagram.

Penentuan rumah sakit ini berdasarkan pendekatan kelas rumah sakit dimana ketiga rumah sakit mewakili kelas A, B dan C. Pemilihan sampel penelitian dilakukan dengan rancangan probability sampling menggunakan teknik cluster sampling.

\section{HASIL DAN PEMBAHASAN}

\section{Karakteristik Pasien}

\section{a. Jenis Kelamin}

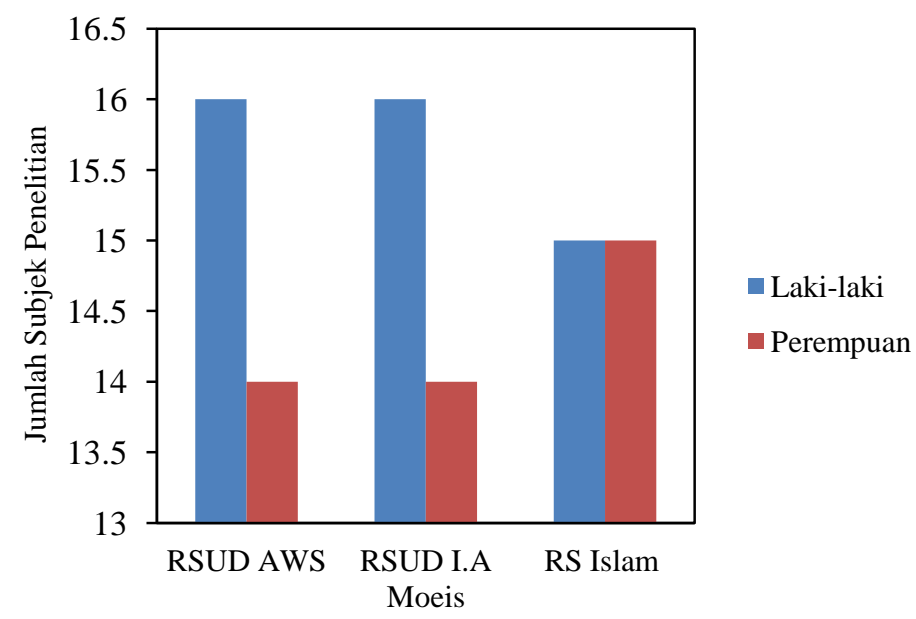

\section{Gambar 1 Distribusi Pasien Demam Tifoid berdasarkan Jenis Kelamin}

Grafik 1 menunjukkan bahwa angka kejadian demam tifoid lebih banyak terjadi pada laki-laki $(52,22 \%)$ dibandingkan dengan perempuan $(47,78 \%)$. Hormon seks mempengaruhi imunitas humoral dan respon imun dimana perempuan memiliki hormon estrogen. Estrogen merupakan hormon yang dapat meningkatkan sitokin yang dilepaskan oleh sel imun, terutama $\mathrm{T}$ helper (Th) limfosit sehingga imunitas yang dimiliki oleh perempuan lebih baik dibandingkan dengan laki-laki (Hirokawa dkk, 2013). Hal ini menyebabkan perempuan lebih sulit untuk terinfeksi. 


\section{b. Usia}

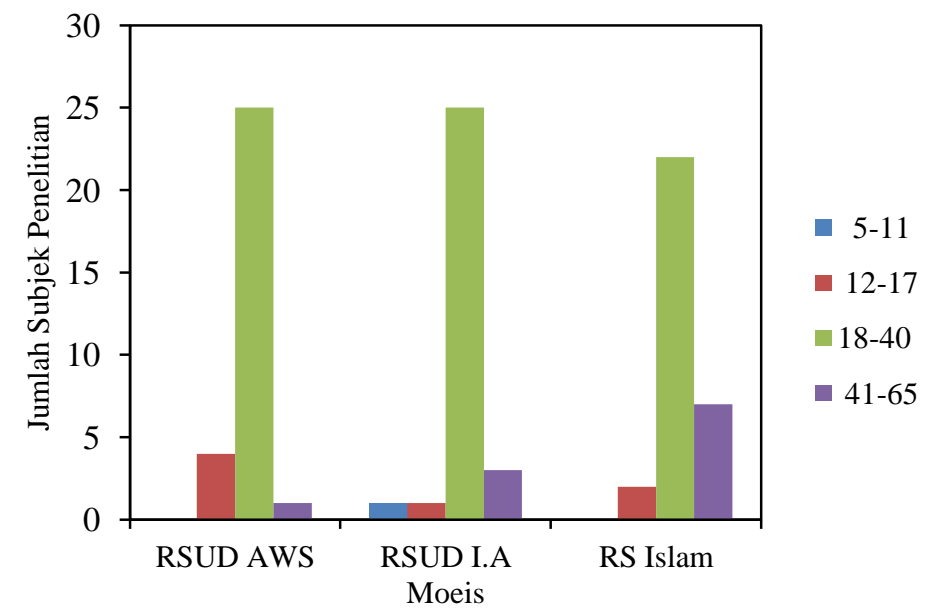

Gambar 2 Distribusi Pasien Demam Tifoid berdasarkan Usia

Grafik 2 menunjukkan pasien demam tifoid terbanyak pada rentang usia 18-40 tahun (dewasa) dengan persentase dari ketiga rumah sakit sebesar $80 \%$. Hal ini disebabkan pada usia dewasa lebih sering melakukan aktivitas di luar rumah dan mengkonsumsi makanan siap saji yang kebersihannya belum terjamin, sehingga tidak menutup kemungkinan bahwa makanan atau minuman yang dikonsumsi di luar rumah tersebut terinfeksi Salmonella thypi (Ayu dkk., 2012).

\section{c. Pendidikan}

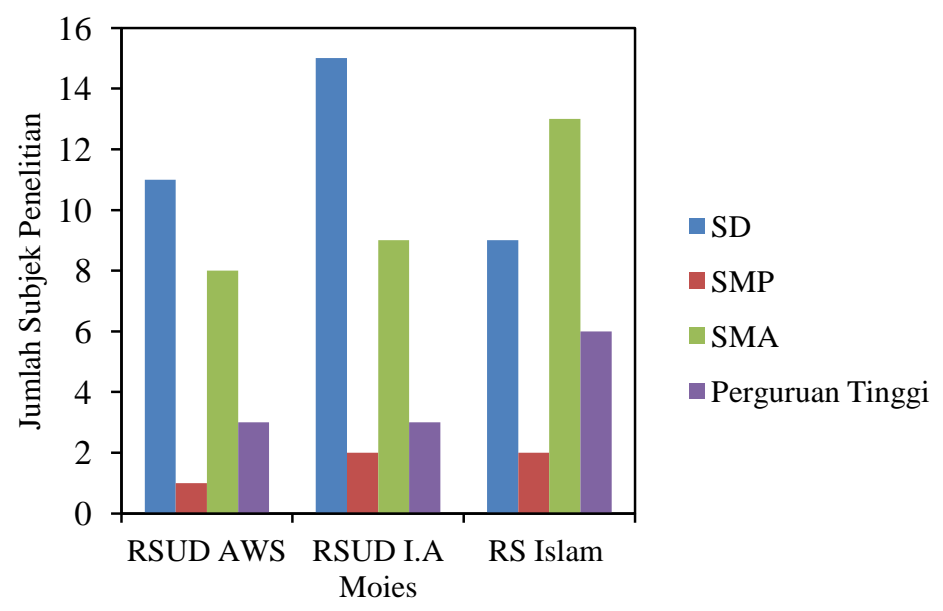

\section{Gambar 3 Distribusi Pasien Demam Tifoid berdasarkan Pendidikan}

Grafik 3 menunjukkan bahwa pasien demam tifoid terbanyak dengan pendidikan Sekolah Dasar (SD) dengan persentase sebesar 42,68\%. Hal ini dikarenakan semakin tinggi pendidikan seseorang maka wawasan yang dimilikinya akan semakin luas sehingga pemahaman mengenai penyakit demam tifoid pun juga akan semakin baik dan akan lebih 
sulit terinfeksi Salmonella typhi dibandingkan seseorang dengan pendidikan yang rendah (Susanti., 2015).

\section{d. Pekerjaan}

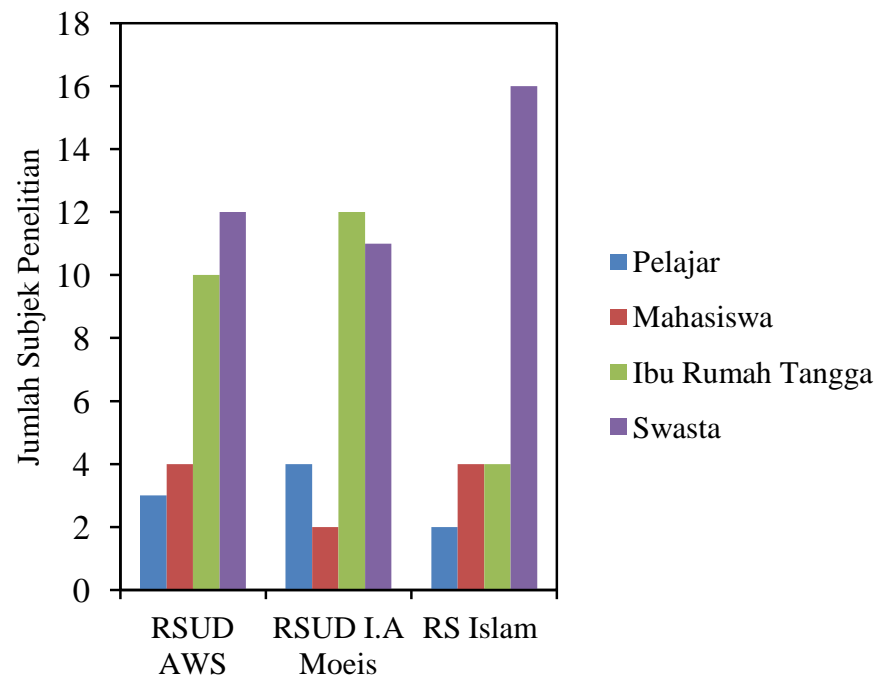

Gambar 4 Distribusi Pasien Demam Tifoid berdasarkan Pekerjaan

Grafik 4 menunjukkan pasien dengan pekerjaan swasta rentan terkena demam tifoid dengan persentase dari ketiga rumah sakit sebesar 46,43\%. Hal ini disebabkan pekerjaan swasta memiliki pola jam kerja yang berbeda jika dibandingkan dengan pelajar, mahasiswa dan ibu rumah tangga sehingga lama bekerja juga berbeda. Jam kerja yang panjang menyebabkan aktivitas yang dilakukan pun lebih banyak sehingga rentan terkena infeksi (Susanti., 2015).

\section{Penggunaan Antibiotik}

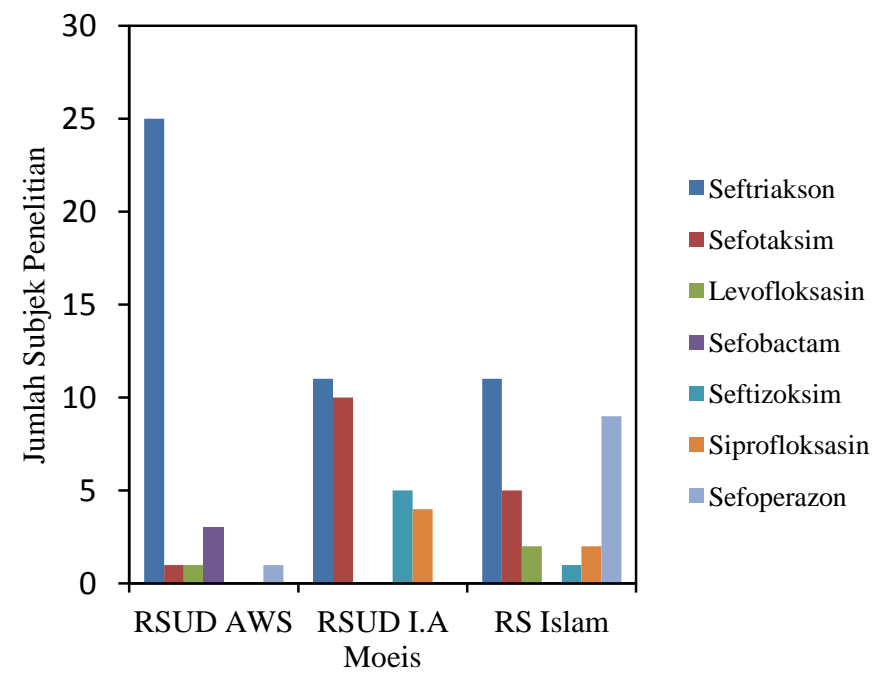

Gambar 5 Profil Penggunaan Antibiotik 
Grafik 5 menunjukkan antibiotik yang banyak digunakan dari ketiga rumah sakit adalah sefalosporin generasi ketiga yaitu seftriakson. Seftriakson merupakan terapi lini kedua untuk demam tifoid, namun tetap digunakan sebagai terapi utama dikarenakan memiliki spektrum yang luas dan jarang terjadi resistensi. Selain itu, memiliki indeks terapeutik yang tinggi dan efek samping minimal sehingga efektif dalam pengobatan demam tifoid (Menkes., 2006). Namun, sebaiknya dilakukan kultur bakteri dulu dalam penggunaannya sehingga pemberian antibiotik akan tepat untuk meminimalkan resistensi.

\section{KESIMPULAN}

1. Karakteristik pasien demam tifoid tertinggi berdasarkan jenis kelamin adalah laki-laki $(52,22 \%)$, berdasarkan usia adalah kelompok umur 18-40 tahun (80 \%), berdasarkan pendidikan adalah SD $(42,68 \%)$ dan berdasarkan pekerjaan adalah swasta $(46,43 \%)$.

2. Penggunaan antibiotik terbanyak pada sefalosporin generasi ketiga yaitu seftriakson $(52,22 \%)$.

\section{DAFTAR PUSTAKA}

1. Ayu, N.S., Junaidi, A. dan Maria, U. 2010. Karakteristik Tersangka Demam Tifoid Pasien Rawat Inap di Rumah Sakit Muhammadiyah Palembang Periode Tahun 2010. Syifa'Medika. 3. (1). Halaman 2-3.

2. Puspitasari, I.R., dan Eman, S. 2011. Cost-Effectiveness Analysis Pengobatan Demam Tifoid Anak Menggunakan Sefotaksim dan Kloramfenikol di RSUD. Prof. Dr. Margono Soekarjo Purwokerto. Mandala of Health. 5. (2). Halaman

3. Depkes RI. 2007. Profil Kesehatan Indonesia Tahun 2007. Departemen Kesehatan Republik Indonesia. Jakarta.

4. Balitbangkes. 2008. Riset Kesehatan Dasar 2007. Departemen Kesehatan Republik Indonesia. Jakarta.

5. Fauci, A. S., Dennis, L. dan, L. Eugene B. Stephen, L. Larry, J. dan Joseph, L. 2008. Harrison's Principles of Internal Medicine $17^{\text {th }}$ Edition. The McGraw-Hill Medical. New York.

6. Musnelina, L., Fuad, A. Ascorbat, G. dan Pratiwi, A. 2004. Pola Pemberian Antibiotika Pengobatan Demam Tifoid Anak di Rumah Sakit Fatmawati Jakarta Tahun 2001 2002. Makara, Kesehatan. 8. (1). Halaman 1-2.

7. Arias, C.A., dan Barbara, E. 2015. A New Antibiotic and the Evolution of Resistance. The New England Journal Medicine. 372. (12). Halaman 1.

8. Kamriyani., Yusran, H. dan Darwis. 2013. Pola Pemberian Antibiotik Pada Pasien di Ruang Perawatan Interna RSUD Kabupaten Pangkep. STIKES Nani Hasanuddin. 2. (1). Halaman 2.

9. Hirokawa, K., Masanori, U. Yoshio, H. Masanobu, K. Takashi, M. dan Tamas, F. 2013. Slower Immune System Aging In Women Versus Men In The Japanese Population. Biomed Central. 10. (19). Halaman 4-6

10. Susanti. 2015. Pengetahuan Keluarga Penderita Demam Tifoid dan Tindakan Pencegahan Demam Tifoid di Dusun Mundu Catur Tunggal Sleman Yogyakarta. Adi Husada Nursing Journal. 1. (2). Halaman 2-3

11. Menteri Kesehatan. 2006. Pedoman Pengendalian Demam Tifoid. Menkes RI. Jakarta 